Bond University

Research Repository

\title{
Possible harms of oseltamivir-a call for urgent action
}

Jefferson, Tom; Jones, Mark; Doshi, Peter; Del Mar, Chris

Published in:

The Lancet

DOI:

10.1016/S0140-6736(09)61804-3

\section{Licence:}

CC BY-NC-ND

Link to output in Bond University research repository.

Recommended citation(APA):

Jefferson, T., Jones, M., Doshi, P., \& Del Mar, C. (2009). Possible harms of oseltamivir-a call for urgent action. The Lancet, 374(9698), 1312-1313. https://doi.org/10.1016/S0140-6736(09)61804-3

\footnotetext{
General rights

Copyright and moral rights for the publications made accessible in the public portal are retained by the authors and/or other copyright owners and it is a condition of accessing publications that users recognise and abide by the legal requirements associated with these rights.
}

For more information, or if you believe that this document breaches copyright, please contact the Bond University research repository coordinator. 


\section{Bond University}

\section{ePublications@bond}

10-17-2009

\section{Possible harms of oseltamivir-A call for urgent action}

Tom Jefferson

Mark Jones

University of Queensland

Peter Doshi

Chris Del Mar

Bond University, chris_del_mar@bond.edu.au

Follow this and additional works at: http://epublications.bond.edu.au/hsm_pubs

Part of the Medicine and Health Sciences Commons

\section{Recommended Citation}

Tom Jefferson, Mark Jones, Peter Doshi, and Chris Del Mar. (2009) "Possible harms of oseltamivir-A call for urgent action" ,, .

http://epublications.bond.edu.au/hsm_pubs/109 


\section{Possible harms of oseltamivir-a call for urgent action}

Oseltamivir is a successful drug: between July, 2004, to June, 2009, more than 11.5 million new prescriptions were issued in the USA, and nearly all influenza pandemic plans recommend antiviral drugs as a mainstay of containment on a population basis and treatment on an individual basis, with oseltamivir preferred because of ease of administration and storage. As $75 \%$ of the world production of oseltamivir has been used in Japan, ${ }^{1}$ this is where to look for any serious harms the drug might cause.

In March, 2007, the Japanese Ministry of Health Labour and Welfare funded two prospective cohort studies, and subsequently advised against oseltamivir's use in children and adolescents aged 10-19 years. The first study was in 2846 children in the winter of 2005-06. This study found evidence of unusual behaviour in recipient children within the first day of infection. ${ }^{1}$ The second larger (>10 000 children) cohort study done the following winter failed to find any positive association. However, the analysis was criticised. ${ }^{1} \mathrm{~A}$ detailed independent review of eight serious cases concluded that three sudden deaths during sleep and two near-deaths, as well as two deaths from accidents resulting from abnormal behaviour in older children and adolescents shortly after taking oseltamivir, were probably related to the central depressant action of oseltamivir. ${ }^{2}$

As part of updating our 2006 Cochrane review on neuraminidase inhibitors, ${ }^{3}$ we are assessing possible harms, and first examined the randomised controlled trials (RCTs). These trials most commonly reported vomiting in adolescents (risk difference $0.05,95 \% \mathrm{Cl} 0.02-0.09$, number needed to harm 20) ${ }^{4}$ and nausea in healthy adults (odds ratio 1.79, 95\% Cl 1.10-2.93), but no behavioural disturbances or deaths. ${ }^{3}$ We looked for harm data outside RCT evidence, submitting a Freedom of Information Act request to the US Food and Drug Administration (FDA) for all harms data in their possession. We received Adverse Event Reporting System (AERS) data from 1999, supplementing the freely accessible FDA AERS data since 2004.,

The FDA dataset includes 2275 initial postmarketing surveillance adverse event reports generated worldwide from December, 1999, to July, 2009 (the date of granting our request). Breakdown by setting and even country is difficult because most reports do not indicate these variables and the only date consistently recorded is the date the FDA received the report (which could be several months or even years after the event). The data do not allow standardisation by doses sold or by level of circulating influenza, which prevents estimates of reporting rates or seasonal trends. Despite these limitations, many $(607 / 1781,34 \%)$ serious harms were reported in people aged below 20 years. Abnormal behaviour, convulsion, delirium, and hallucinations were more common in the young, while other adverse effects (diarrhoea, headache, nausea, loss of consciousness, pyrexia, and vomiting) were not. The most common globally reported potential harms (those which generated at least 50 reports) for oseltamivir are shown in the table.

Since July, 2005, the reporting country was identified in $99.6 \%$ of reports. The US reporting rate of adverse events was 0.43 per 10000 total oseltamivir prescription counts from July, 2005, to March, 2009. However, the FDA AERS data were not of sufficient quality to answer our study question. For example, adverse events listed for each report were given in alphabetical order, not in order of importance. 
Information about the patient's setting, symptoms, and timing of the event were often insufficiently precise, missing, or absent, which made interpretation of reports impossible. Reports of delirium and confusion could be caused by oseltamivir in children and adolescents. But they could equally be a manifestation of a high temperature due to influenza or influenza-like illness. ${ }^{7}$ Finally, national pandemic stockpiling as well as personal stockpiling indicates that neither sales nor even prescription data may equate with exposure to the drug. ${ }^{8}$

Despite these inadequate data, the consistent reports of potential serious harms in adolescents, and the projected future heavy use of oseltamivir, make it imperative to quickly establish large multicentre studies to test any possible associations. The choice of design might prove controversial. Ethical concerns or a supposed rare incidence suggest a case-control design. But if the best estimates from Japan are reliable (a 3\% incidence in children using oseltamivir for behavioural changes within a few days - estimates that beg the question of why registration trials did not pick them up), RCTs would be the best. Whichever way, we are running out of time to find answers.

Tom Jefferson, Mark Jones, Peter Doshi, *Chris Del Mar Cochrane Acute Respiratory Infections Group, Anguillara Sabazia, Italy (TJ); School of Population Health, University of Queensland, Herston, Qld 4006 Australia (MJ); Massachusetts Institute of Technology, Cambridge, MA, USA (PD); and Faculty of Health Sciences and Medicine, Bond University, Gold Coast, Qld 4229, Australia cdelmar@bond.edu.au

We declare that we have no conflicts of interest.

We gratefully acknowledge funding from the UK NHRI and the Australian NHMRC.

1 Yorifuji T, Suzuki E, Tsuda T. Oseltamivir and abnormal behaviours: true or not? Epidemiology 2009; 20: 1-3.

2 Hama R. Fatal neuropsychiatric adverse reactions to oseltamivir: case series and overview of causal relationships. Int J Risk Safety Med 2008; 20: 5-36.

3 Jefferson T, Demicheli V, Di Pietrantonj C, Jones M, Rivetti D. Neuraminidase inhibitors for preventing and treating influenza in healthy adults. Cochrane Database Syst Rev 2006; 3: CD001265.

4 Shun-Shin M, Thompson M, Heneghan C, et al. Neuraminidase inhibitors for treatment and prophylaxis of influenza in children: systematic review and metaanalysis of randomised controlled trials. BMJ 2009; 339: b3172.

5 U.S. Food and Drug Administration. The Adverse Event Reporting System (AERS): older quarterly data files. July 28 ,

2009. http://www.fda.gov/Drugs/GuidanceComplianceRegulatorylnformation/Surveill ance/AdverseDrugEffects/ucm083765.htm (accessed Sept 1, 2009).

6 U.S. Food and Drug Administration. The Adverse Event Reporting System (AERS): latest quarterly data files. July 28 ,

2009. http://www.fda.gov/Drugs/GuidanceComplianceRegulatorylnformation/Surveill ance/AdverseDrugEffects/ucm082193.htm (accessed Sept 1, 2009).

7 Nicholson KG. Clinical features of influenza. Semin Respir Infect 1992; 7: 26-37.

8 Ortiz JR, Kamimoto L, Aubert RE, et al. Oseltamivir prescribing in pharmacybenefits database, United States, 2004-2005. Emerg Infect Dis 2008: 14: 1280-03. 
Table: Most frequently reported potential harms after ingestion of oseltamivir (up to 20 per patient) by age-group according the US FDA AERS postmarketing surveillance database, $1999-2009$.

From initial reports only. AERS database describes events with the Preferred Term (PT) level medical terminology, with use of the Medical Dictionary for Regulatory Activities (MedDRA).

\begin{tabular}{|c|c|c|c|c|}
\hline $\begin{array}{l}\text { Description of } \\
\text { event }\end{array}$ & $\begin{array}{l}\text { Age }<20 \text { years } \\
(n=607)\end{array}$ & $\begin{array}{l}\text { Age }>20 \\
\text { years } \\
(n=1174)\end{array}$ & $\begin{array}{l}\text { Missing age } \\
(n=494)\end{array}$ & $\begin{array}{l}\text { Total } \\
(n=2275)\end{array}$ \\
\hline $\begin{array}{l}\text { Abnormal } \\
\text { behaviour }\end{array}$ & 145 & 34 & 34 & 213 \\
\hline $\begin{array}{l}\text { Confusional } \\
\text { state }\end{array}$ & 15 & 28 & 14 & 57 \\
\hline Convulsion & 49 & 37 & 12 & 98 \\
\hline Delirium & 54 & 23 & 15 & 92 \\
\hline Diarrhoea & 20 & 42 & 21 & 83 \\
\hline Hallucination & 89 & 35 & 21 & 145 \\
\hline Headache & 9 & 30 & 12 & 51 \\
\hline $\begin{array}{l}\text { Loss of } \\
\text { consciousness }\end{array}$ & 18 & 34 & 0 & 52 \\
\hline Nausea & 13 & 63 & 30 & 106 \\
\hline Pyrexia & 18 & 36 & 12 & 66 \\
\hline Vomiting & 49 & 92 & 50 & 191 \\
\hline
\end{tabular}

